\title{
Disaccharide Synthesis by Enzymatic Condensation of Glucose: Glycoside Linkage Patterns for Different Fungal Species
}

\author{
Margarita V. Semenova ${ }^{a}$, Oleg N. Okunev ${ }^{b}$, Alexander V. Gusakov*,c and Arkady P. Sinitsyn*,a,c \\ ${ }^{a}$ A. N. Bach Institute of Biochemistry, Russian Academy of Sciences, Lininsky Pr. 33, Moscow 119071, Russia; ${ }^{b}$ Institute \\ of Biochemistry and Physiology of Microorganisms, Russian Academy of Sciences, Pushchino 142292, Russia; \\ ${ }^{c}$ Department of Chemistry, M. V. Lomonosov Moscow State University, Moscow 119991, Russia
}

\begin{abstract}
Four enzyme preparations produced by fungal species belonging to different genera (Aspergillus niger, Corynascus sp., Penicillium verruculosum, Trichoderma reesei) were used for synthesis of disaccharides by D-glucose (60\% w/v) condensation catalyzed by $\beta$-glucosidase. Effects of $\mathrm{pH}$ and temperature on the disaccharide synthesis were studied, and glycoside linkage patterns for enzymes from different sources were determined. The highest concentration of disaccharides (114 and $118 \mathrm{~g} / \mathrm{l})$ was achieved in the case of A. niger and Corynascus sp. enzymes after $48 \mathrm{~h}$ of the condensation reaction carried out at $70{ }^{\circ} \mathrm{C}$ and optimal $\mathrm{pH}$; the $P$. verruculosum sample slightly conceded them in the yield of products $(96 \mathrm{~g} / \mathrm{l})$, while the $T$. reesei preparation displayed the lowest synthetic activity $(35 \mathrm{~g} / \mathrm{l})$. Gentiobiose was predominantly formed in the reaction catalyzed by the first three enzyme samples, while in the case of $T$. reesei laminaribiose was the main condensation product.
\end{abstract}

Keywords: $\beta$-Glucosidase, Condensation, Cellobiose, Gentiobiose, Laminaribiose, Sophorose.

\section{INTRODUCTION}

Glycoside hydrolases (EC 3.2.1.-) catalyzing the hydrolysis of polysaccharides and/or low-molecular glycosides with overall retention of the anomeric configuration are also able, under certain conditions, to catalyze the formation of glycosidic bonds via transglycosylation and condensation (reverse hydrolysis) [1-3]. Transglycosylation is a kinetically controlled reaction, while the reverse hydrolysis is under thermodynamic control. The synthetic activity of glycosidases has been used for production of oligosaccharides [412], alkyl-glycosides [12-17], vitamin derivatives [18]. Oligosaccharides are used as therapeutic agents, diagnostic tools, and additives in the food and cosmetic industries [8, $12,19,20]$. Alkyl-glycosides found applications as non-ionic surfactants in detergents, cosmetics, foods and pharmaceuticals $[12,13,20]$. The enzymatic synthesis of glycosides has certain advantages over chemical synthesis, since it is carried out under mild conditions in one stereoselective step, while being more regioselective $[8,13,17]$.

The most widely used enzymes for oligosaccharide and alkyl-glycoside synthesis are $\beta$-glucosidases (EC 3.2.1.21), which act on terminal non-reducing $\beta$-D-glucosyl residues in cellooligosaccharides and other $\beta$-D-glucosides with release of $\beta$-D-glucose [20]. Different $\beta$-glucosidases from fungi, bacteria and plants have been used in transglycosylation and condensation reactions [4-17, 20-24], which are usually carried at high substrate concentration in order to attain higher yields of products. Trisaccharides and higher oligomers are formed as major transglycosylation products of $\beta$-gluco-

*Address correspondence to these authors at the Department of Chemistry, M.V. Lomonosov Moscow State University, Moscow 119991, Russia; Tel: +7 495939 5966; Fax: +7 495939 0997;

E-mails: avgusakov@enzyme.chem.msu.ru; apsinitsyn@enzyme.chem.msu.ru sidase-catalyzed reactions with cellobiose as a substrate $[5$, $6,8,10,12,20,22]$, while the condensation reactions with glucose as a substrate lead to preferential formation of disaccharides $[4,9-11,20]$. Although the typical yields of products in the condensation reaction $(10-25 \%)[10,11,20]$ are usually lower than those obtained with transglycosylation $(15-40 \%)[5,6,10,12,20,22]$, the substrates (monosaccharides) for condensation are cheaper and the reaction can be more easily controlled. With $90 \%$ glucose as a substrate, the unusually high yield of disaccharides $(40 \%)$ was obtained in reverse hydrolysis reaction catalyzed by almond $\beta$ glucosidase [4], while the yields of several oligosaccharides up to $65 \%$ have been achieved by utilizing the transglycosylation activity of Agrobacterium sp. $\beta$-glucosidase [24].

The preferential formation of the $\beta$-1,6-glucosidic linkage has been observed in both transglycosylation and condensation reactions catalyzed by $\beta$-glucosidases of fungal (Aspergillus spp., Trichoderma spp.) and plant (almond, Thai rose wood) origin $[4,8,9,20-23]$. Together with gentiobiose $(\beta-1,6$-linkage), smaller amounts of sophorose $(\beta$ $1,2)$, laminaribiose $(\beta-1,3)$ and cellobiose $(\beta-1,4)$ have been detected amongst products of glucose condensation [4,9], while a notable amount of trehalose $(\alpha-1,1)$ has been formed by $\beta$-glucosidase from $T$. pseudokoningii in the reaction system containing cellobiose and glucose as initial substrates [23]. Rather unusual biosynthetic activity in the order of sophorose > gentiobiose > cellobiose has been reported for the recombinant Pichia etchellsii $\beta$-glucosidase II [10].

However, in spite of the numerous publications on $\beta$ glucosidase-catalyzed transglycosylation and condensation, the number of organisms studied from this point of view, is rather limited. One may expect that enzymes from different organisms would form oligosaccharides with different yields and various ratios between synthesized products. 
This paper focuses on the reaction of glucose condensation catalyzed by enzyme preparations produced by fungal species belonging to four different genera (Aspergillus, Corynascus, Penicillium, Trichoderma). All enzyme samples possessed $\beta$-glucosidase activity to catalyze the reverse hydrolysis reaction within reasonable time. Effects of $\mathrm{pH}$ and temperature on the synthesis of disaccharides were studied, and glycoside linkage patterns for enzymes from different sources were determined.

\section{MATERIALS AND METHODS}

\section{Enzymes}

Crude enzyme preparations produced by fungal species belonging to four different genera were used for disaccharide synthesis from glucose, that is, Celloviridin G20x (Trichoderma reesei), Aspergillus niger, Corynascus sp., Penicillium verruculosum. The first preparation was a commercial one, produced by "Promferment" company (Russia), while the other enzyme samples were laboratory preparations obtained in the Institute of Biochemistry and Physiology of Microorganisms, Russian Academy of Sciences. The specific $\beta$-glucosidase activity of the preparations determined with $p$ nitrophenyl- $\beta$-D-glucoside (Sigma, USA) as a substrate at $\mathrm{pH} 5.0$ and $40{ }^{\circ} \mathrm{C}$ [25] was $0.3,41.0,18.5$ and $1.3 \mathrm{U} / \mathrm{mg}$ protein, respectively.

\section{Condensation Reaction}

The condensation reaction was carried out with $60 \%$ (w/v) D-glucose (Reakhim, Russia) as a substrate in plastic tubes ( $1.5 \mathrm{ml}$ volume) placed on the thermostated shaker ( 50 , 60,65 or $70{ }^{\circ} \mathrm{C}$ ) at different $\mathrm{pH}$ using $20 \mathrm{mM}$ Na-acetate buffers. The enzyme dosage in a typical experiment was either 4 or $8 \mathrm{mg}$ of protein per $1 \mathrm{ml}$. Aliquots of the reaction mixture $(0.1 \mathrm{ml})$ were taken at various reaction time, they were diluted with distilled water and analyzed by HPLC.

\section{Analysis of the Reaction Products}

The products of glucose condensation were analyzed by HPLC on a Workstation 700 system (Bio-Rad Laboratories, USA) equipped with a refractometric detector, using a Diasorb 130 Amino column (4 x $250 \mathrm{~mm}, 6 \mu \mathrm{m}$ ) from BioChemMack (Russia) and acetonitrile/water mixture (80:20) as a mobile phase. Sophorose (Serva, Germany), laminaribiose (Megazyme, Australia), cellobiose (Merck, Germany) and gentiobiose (Sigma, USA) were used as standards in the HPLC analysis.

\section{RESULTS AND DISCUSSION}

Crude enzyme preparations produced by fungal species belonging to four different genera (Aspergillus, Corynascus, Penicillium, Trichoderma) were used for disaccharide synthesis by enzymatic condensation of D-glucose. The condensation reaction is typically carried out at high glucose concentration (30-90\%). We used $60 \%$ (w/v) glucose as a substrate and carried out the enzymatic process for 5 days at different temperatures $\left(50,65,70\right.$ and $\left.75{ }^{\circ} \mathrm{C}\right)$. The formation of the condensation products was monitored by HPLC. A typical chromatogram is shown in Fig. (1).

For all enzymes under study, four disaccharides with different glucoside linkages were formed as the condensation products, that is, laminaribiose, cellobiose, sophorose and gentiobiose. In these disaccharides the glucosidic residues are connected by $\beta-1,3-, \beta-1,4-, \beta-1,2-$ and $\beta-1,6-$ linkage, respectively. The ratio between disaccharides varied depending on the enzyme source (Fig. 1). Gentiobiose was predominantly formed in the reaction catalyzed by the A. niger, Corynascus sp. and $P$. verruculosum enzymes, while in the case of the $T$. reese $i$ sample laminaribiose was the main condensation product.
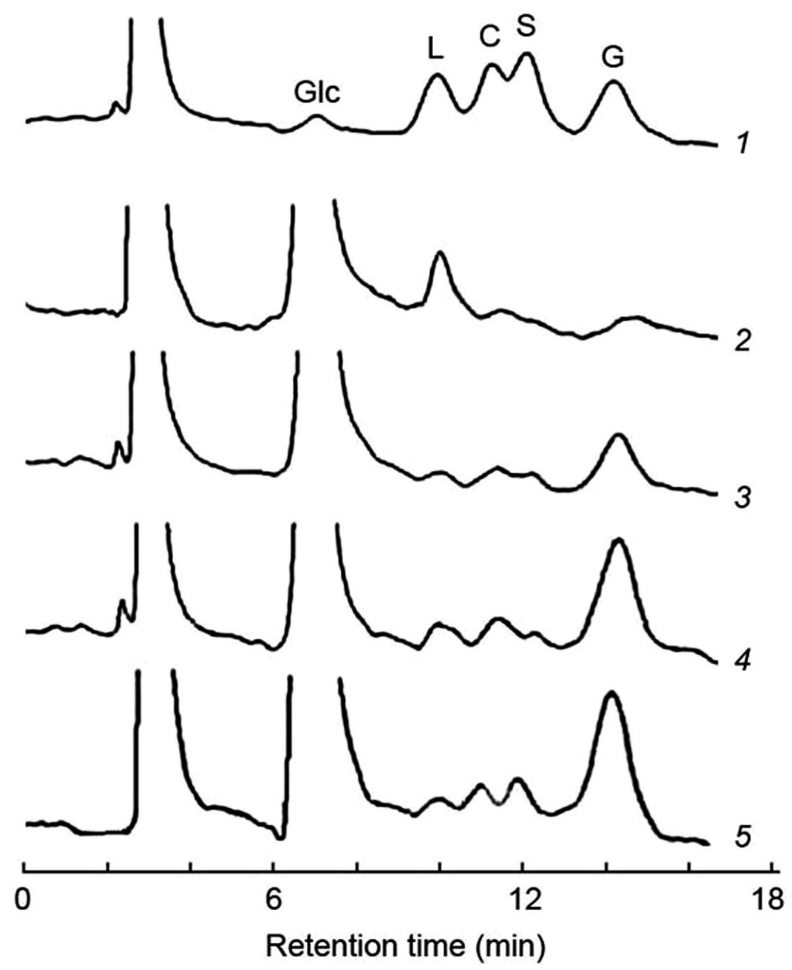

Fig. (1). HPLC analysis of the glucose condensation products using a silica column with bonded amino phase and acetonitrile-water (80:20) as a mobile phase at a flow rate of $1 \mathrm{ml} / \mathrm{min}$. 1 , chromatographic standards: laminaribiose (L), cellobiose (C), sophorose (S), gentiobiose (G); 2, T. reesei; 3, P. verruculosum; 4, A. niger; 5, Corynascus sp.

Since the condensation reaction is known to be controlled by thermodynamics [1-3], one may expect that the increase in temperature would result in shorter time to attain the equilibrium. Indeed, while at $50{ }^{\circ} \mathrm{C}$ the total concentration of disaccharides gradually increased with time and it still did not achieve maximum even after 5 days of the reaction, at higher temperatures $\left(65-75^{\circ} \mathrm{C}\right)$ the maximum disaccharide concentration was achieved after 2 days of the process. As an example, Fig. (2) shows the kinetics of the condensation reaction catalyzed by $P$. verruculosum enzyme preparation at $\mathrm{pH} 4.5$ and protein dosage of $4 \mathrm{mg} / \mathrm{ml}$, while Fig. (3) shows the yields of disaccharides after 2 or 5 days for different enzyme samples at various temperatures. For all fungal species the maximum yield of disaccharides was observed at either $65-70{ }^{\circ} \mathrm{C}$ (A. niger) or $70{ }^{\circ} \mathrm{C}$ (other enzymes). This result was rather unexpected. Fungal enzymes, including $\beta$ glucosidases, are typically unstable at such temperature [25, 26]. So, enzymatic processes lasting a few days, such as enzymatic hydrolysis of cellulose, are usually performed at a lower temperature $\left(\sim 50^{\circ} \mathrm{C}\right)[27,28]$. On the other hand, substrates, like low-molecular-weight sugars, may cause stabili- 
zation effects on enzymes [26]. We carried out the condensation reaction at very high glucose concentration $(60 \%)$, so the substrate seems to stabilize the enzymes dramatically. All further experiments were carried out at $70{ }^{\circ} \mathrm{C}$ for $48 \mathrm{~h}$.

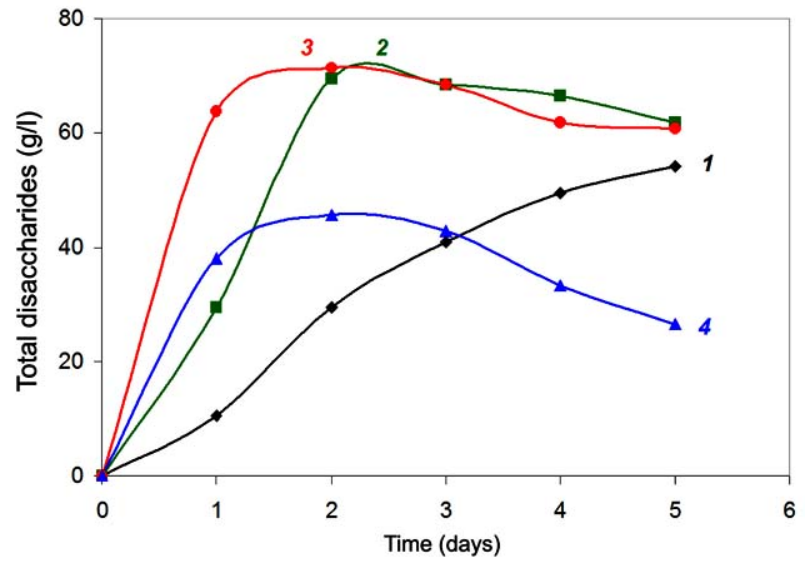

Fig. (2). Kinetics of disaccharide formation in the glucose $(60 \%$ w/v) condensation reaction catalyzed by $P$. verruculosum enzyme at $\mathrm{pH} 4.5$ and protein dosage of $4 \mathrm{mg} / \mathrm{ml} .1,50{ }^{\circ} \mathrm{C} ; 2,65{ }^{\circ} \mathrm{C} ; 3,70{ }^{\circ} \mathrm{C}$; $4,75^{\circ} \mathrm{C}$.

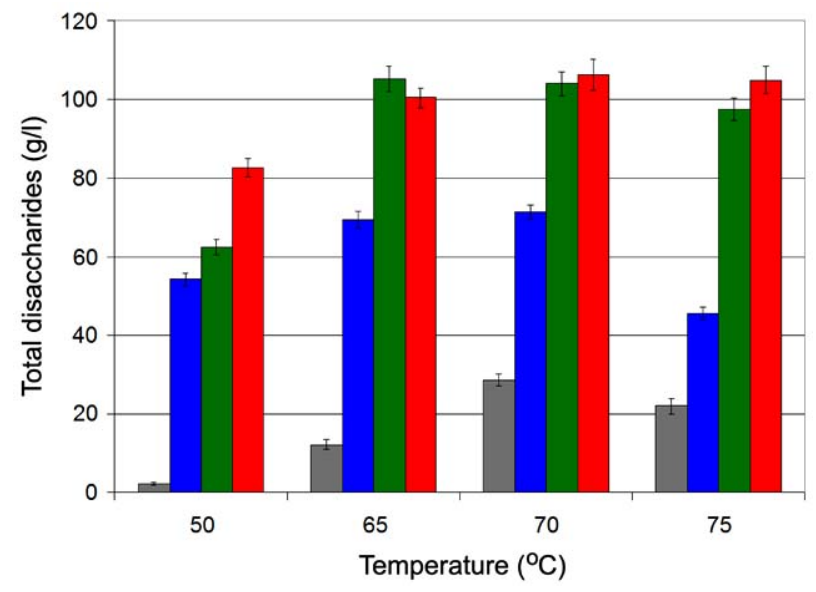

Fig. (3). Disaccharide production from $60 \%(w / v)$ glucose by fungal enzymes at $\mathrm{pH} 4.5$ and different temperatures using protein loading of $4 \mathrm{mg} / \mathrm{ml}:$ T reesei (grey), P. verruculosum (blue), A. niger (green), Corynascus sp. (red). The reaction time was $120 \mathrm{~h}$ $\left(50{ }^{\circ} \mathrm{C}\right)$ or $48 \mathrm{~h}\left(65,70,75^{\circ} \mathrm{C}\right)$.

The effect of $\mathrm{pH}$ on the yields of disaccharides is shown in Fig. (4). For T. reesei and P. verruculosum enzymes, the maximum disaccharide synthesis was observed at $\mathrm{pH} 4.5$, while for the A. niger and Corynascus sp. preparations the optimum was found at $\mathrm{pH} 4.0$ and 3.5 , respectively. It is interesting to note that the purified $\beta$-glucosidases isolated in our laboratory from the fungal species under study had $\mathrm{pH}-$ optima of hydrolytic activity at $\mathrm{pH} 5.5$ (P. verruculosum), 5.0 (T. reesei), 4.5 (A. niger) [25] and 4.0 (Corynascus sp., unpublished data). So, in all cases the enzyme $\mathrm{pH}$-optimum for oligosaccharide synthesis by condensation seems to be shifted to acidic $\mathrm{pH}$ region (by 0.5-1.0 unit of $\mathrm{pH}$ ) compared to the hydrolytic $\mathrm{pH}$-optimum of the same enzyme.

The total concentrations of disaccharides synthesized from $60 \%(\mathrm{w} / \mathrm{v})$ glucose by different enzyme preparations

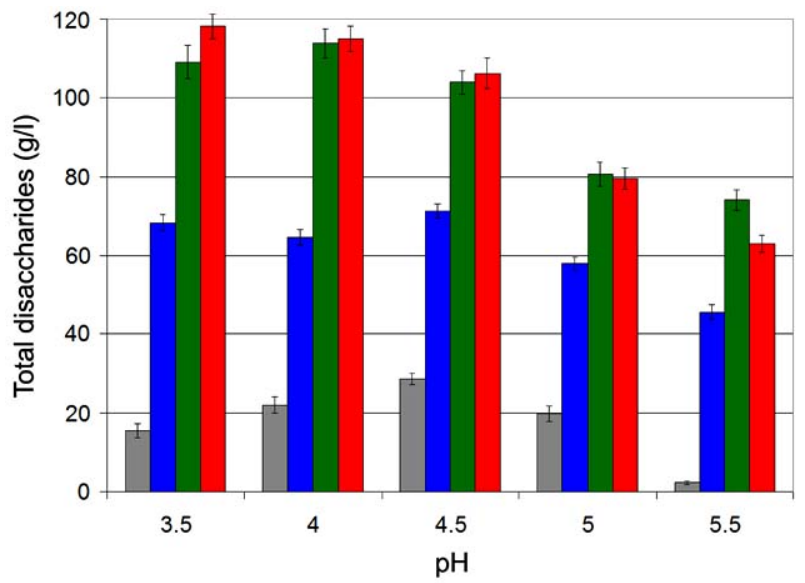

Fig. (4). Disaccharide production from $60 \%(w / v)$ glucose at different $\mathrm{pH}$ after $48 \mathrm{~h}$ of the enzymatic reaction at $70{ }^{\circ} \mathrm{C}$ and protein loading of $4 \mathrm{mg} / \mathrm{ml}$ : T. reesei (grey), P. verruculosum (blue), A. niger (green), Corynascus sp. (red).

after $48 \mathrm{~h}$ of the condensation reaction at $70{ }^{\circ} \mathrm{C}$ and optimal $\mathrm{pH}$ as well as the composition of each product mixture, determined by HPLC, are presented in Table 1. It should be noted that the dosage of A. niger and Corynascus sp. enzymes was $4 \mathrm{mg}$ of protein per $\mathrm{ml}$, while in the case of $T$. reesei and $P$. verruculosum the enzyme dosage was $8 \mathrm{mg} / \mathrm{ml}$. These protein dosages correspond to the $\beta$-glucosidase activity of $164,74,2.4$ and $10.4 \mathrm{U} / \mathrm{ml}$, respectively. For the first two samples, the increase in the enzyme concentration did not result in the improvement of the product yield (the yield even slightly decreased), while at the double dosage of $T$. reesei and $P$. verruculosum enzymes the disaccharide yield increased by $25-35 \%$ (data are not shown); that was evidently the result of much lower $\beta$-glucosidase activity of the last two preparations.

The highest concentration of disaccharides (114-118 g/l) was achieved in the case of A. niger and Corynascus sp. enzymes; the $P$. verruculosum sample slightly conceded them in the yield of condensation products. The total yields of disaccharides made up 20,21 and $17 \%$ of the theoretical yield, respectively. All the mentioned enzyme preparations formed gentiobiose as a major product (more than 50-60\% of the total disaccharides). The $T$. reesei preparation displayed much lower synthetic efficiency (the yield of disaccharides was only $6 \%$ of the theoretical), laminaribiose being the main condensation product. Perhaps, the lower yield of products was the result of the lowest $\beta$-glucosidase activity of this enzyme sample compared to the other enzymes under study.

Relatively high levels of sophorose in the disaccharide mixtures produced by Corynascus and Penicillium enzymes (13 and 10\%) deserve a special attention. It is believed that sophorose play an important role in the induction of cellulase biosynthesis by fungi $[29,30]$. The use of gentiobiose as an inductor of enzyme biosynthesis has also been reported [30]. Cellulases are important commercial enzymes produced on a large scale by many companies in the world, and they are used in different biotechnological applications $[31,32]$. The process of renewable lignocellulosic biomass conversion to ethanol and other useful products may become the most im- 
Table 1. Disaccharide Synthesis from 60\% (w/v) Glucose Using Enzymatic Condensation Reaction $\left(48\right.$ h, pH 3.5-4.5, 70 $\left.{ }^{\circ} \mathrm{C}\right)$

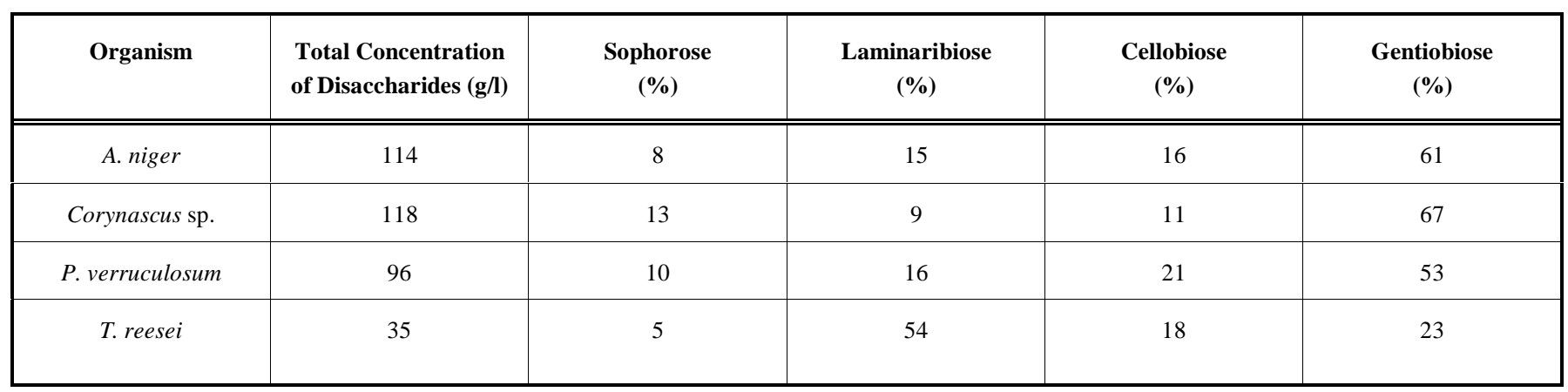

portant cellulase application in the near future. Unlike cellobiose and laminaribiose that can be produced by hydrolysis of widely abundant polysaccharides (cellulose, laminarin, curdlan), sophorose and gentiobiose should be obtained by a different way. The enzymatic synthesis of these disaccharides from glucose by the condensation reaction may become a simple and inexpensive method, if reasonable yields of the products are obtained.

\section{REFERENCES}

[1] Sinnott ML. Catalytic mechanisms of enzymic glycoside transfer. Chem Rev 1990; 90: 1170-202.

[2] McCarter JD, Withers SG. Mechanisms of enzymatic glycoside hydrolysis. Curr Opin Struct Biol 1994; 4: 885-92.

[3] Faber K. In: Faber K, Ed. Biotransformations in Organic Chemistry. Berlin, Springer-Verlag 1997; 275-87.

[4] Ajisaka K, Nishida H, Fujimoto H. The synthesis of oligosaccharides by the reversed hydrolysis reaction of $\beta$-glucosidase at high temperature. Biotechnol Lett 1987; 9: 243-8.

[5] Christakopoulos P, Kekos D, Macris BJ, Goodenough PW, Bhat MK. Optimization of $\beta$-glucosidase catalysed synthesis of trisaccharides from cellobiose and gentiobiose. Biotechnol Lett 1994; 16: 587-92.

[6] Kuriyama K, Tsuchiya K, Murui T. Some properties of transglycosylation activity of sesame $\beta$-glucosidase. Biosci Biotech Biochem 1995; 59: 1142-3.

[7] Prade H, Mackenzie LF, Withers SG. Enzymatic synthesis of disaccharides using Agrobacterium sp. $\beta$-glucosidase. Carbohydr Res 1998; 305: 371-81.

[8] Kono H, Waelchili MR, Fujiwara M, Erata T, Takai M. Regioselective syntheses of new tri- and tetrasaccharides from $\beta$ glucobioses by Trichoderma viride $\beta$-glucosidase and their structural analyses by NMR spectroscopy. Carbohydr Res 1999; 321: 67-74.

[9] Srisomsap C, Subhasitanout P, Techasakul S, Surarit R, Svasti J. Synthesis of homo- and hetero-oligosaccharides by Thai rose wood $\beta$-glucosidase. Biotechnol Lett 1999; 21: 947-51.

[10] Bhatia Y, Mishra S, Bisaria VS. Biosynthetic activity of recombinant Escherichia coli expressed Pichia etchellsii $\beta$-glucosidase II. Appl Biochem Biotechnol 2002; 102-103: 367-79.

[11] Bruins ME, Strubel M, van Lieshout JFT, Janssen AEM, Boom RM. Oligosaccharide synthesis by the hyperthermostable $\beta$ glucosidase from Pyrococcus furiosus: kinetics and modeling. Enzyme Microb Technol 2003; 33: 3-11.

[12] Smaali I, Maugard T, Limam F, Legoy M-D, Marzouki N. Efficient synthesis of gluco-oligosaccharides and alkyl-glucosides by transglycosylation activity of $\beta$-glucosidase from Sclerotinia sclerotiorum. World J Microbiol Biotechnol 2007; 23: 145-9.

[13] Panintrarux C, Adachi S, Araki Y, Kimura Y, Matsuno R. Equilibrium yield of $n$-alkyl- $\beta$-D-glucoside through condensation of glucose and $n$-alcohol by $\beta$-glucosidase in a biphasic system. Enzyme Microb Technol 1995; 17: 32-40.
[14] Panintrarux C, Adachi S, Matsuno R. $\beta$-Glucosidase-catalyzed condensation of glucose with 2-alcohols in buffer-saturated alcohols. Biotechnol Lett 1997; 19: 899-902.

[15] Ducret A, Trani M, Lortie R. Comparison between various commercial sources of almond $\beta$-glucosidase for the production of alkyl glucosides. J Mol Catal B Enzym 2006; 38: 91-4.

[16] Turner P, Svensson D, Adlercreutz P, Karlsson EN. A novel variant of Thermotoga neapolitana $\beta$-glucosidase B is an efficient catalyst for the synthesis of alkyl glucosides by transglycosylation. J Biotechnol 2007; 130: 67-74.

[17] Wang R, Yang X, Gao R, Yang Y, Wang X, Cao S. Enzymatic synthesis of cyclohexyl- $\alpha$ and $\beta$-D-glucosides in a biphase system. J Mol Catal B Enzym 2009; 56: 131-5.

[18] Murase H, Yamauchi R, Kato K, Kunieda T, Terao J. Synthesis of a novel vitamin $\mathrm{E}$ derivative, 2-( $\alpha$-D-glucopyranosyl)methyl2,5,7,8-tetramethylchroman-6-ol, by $\alpha$-glucosidase-catalyzed transglycosylation. Lipids 1997; 32: 73-8.

[19] Varki A. Biological roles of oligosaccharides. All the theories are correct. Glycobiology 1993; 3: 97-130.

[20] Bhatia Y, Mishra S, Bisaria VS. Microbial $\beta$-glucosidases: cloning, properties and applications. Crit Rev Biotechnol 2002; 22: 375407.

[21] Seidle HF, Huber RE. Transglucosidic reactions of the Aspergillus niger Family $3 \beta$-glucosidase: qualitative and quantitative analyses and evidence that the transglucosidic rate is independent of $\mathrm{pH}$. Arch Biochem Biophys 2005; 436: 254-64.

[22] Gusakov AV, Sinitsyn AP, Goldsteins GH, Klyosov AA. Kinetics and mathematical model of hydrolysis and transglycosylation catalyzed by cellobiase. Enzyme Microb Technol 1984; 6: 275-82.

[23] Dong W, Yinbo QU, Peiji G. Transglycosylation of extracellular $\beta$ glucosidase of Trichoderma pseudokoningii S38 and its function in regulation of cellulase biosynthesis. J Gen Appl Microbiol 1996; 42: 363-9.

[24] Prade H, Mackenzie LF, Withers SG. Enzymatic synthesis of disaccharides using Agrobacterium sp. $\beta$-glucosidase. Carbohydr Res 1998; 305: 371-81.

[25] Korotkova OG, Semenova MV, Morozova VV, et al. Isolation and properties of fungal $\beta$-glucosidases. Biochemistry (Moscow) 2009; 74: 569-577.

[26] Gusakov AV, Sinitsyn AP, Klyosov AA. Enzymatic hydrolysis of cellulose. Inactivation and stabilization of individual components of cellulase complexes. Biokhimiya 1982; 47: 1322-31.

[27] Gusakov AV, Sinitsyn AP, Manenkova JA, Protas OV. Enzymatic conversion of industrial and agricultural lignocellulosic wastes: main features of the process. Appl Biochem Biotechnol 1992; 3435: 625-37.

[28] Berlin A, Gilkes N, Kilburn D, et al. Evaluation of cellulase preparations for hydrolysis of hardwood substrates. Appl Biochem Biotechnol 2006; 129-132: 528-45.

[29] Sternberg D, Mandels M. Induction of cellulolytic enzymes in Trichoderma reesei by sophorose. J Bacteriol 1979; 139: 761-9.

[30] Suto M, Tomita F. Induction and catabolite repression mechanisms of cellulase in fungi. J Biosci Bioeng 2001; 92: 305-11. 
[31] Godfrey T, West S, Eds. Industrial Enzymology. $2^{\text {nd }}$ ed. London: Macmillan Press Ltd 1996.
[32] Clarke AJ. Biodegradation of Cellulose. Enzymology and Biotechnology. Lancaster: Technomic Publishing Company 1997.

Received: March 26, 2009

Revised: May 21, 2009

Accepted: May 29, 2009

(C) Semenova et al.; Licensee Bentham Open.

This is an open access article licensed under the terms of the Creative Commons Attribution Non-Commercial License (http://creativecommons.org/licenses/by-nc/3.0/) which permits unrestricted, non-commercial use, distribution and reproduction in any medium, provided the work is properly cited. 